STUDIA PRAWNO-EKONOMICZNE, T. CXII, 2019

PL ISSN 0081-6841; e-ISSN 2450-8179 $\quad$ s. 27-45

https://doi.org/10.26485/SPE/2019/112/2

\title{
Barbara GACH*
}

iD https://orcid.org/0000-0002-3274-5547

\section{TWORZENIE PARKÓW NARODOWYCH W POLSCE LUDOWEJ NA PRZYKŁADZIE OJCOWSKIEGO PARKU NARODOWEGO}

\begin{abstract}
(Streszczenie)
Przedmiotem niniejszego artykułu jest proces tworzenia parku narodowego w czasach Polski Ludowej (1944-1989). Opracowanie to ma na celu przybliżenie zagadnień prawnych związanych $\mathrm{z}$ utworzeniem parku narodowego i wynikających w praktyce $\mathrm{z}$ tego tytułu trudności. Analiza zagadnienia została opracowana na przykładzie Ojcowskiego Parku Narodowego znajdującego się na Wyżynie Krakowsko-Częstochowskiej, w odległości ok. 16 km na północ od Krakowa. Powstały w roku 1956 Ojcowski Park Narodowy, będący najmniejszym polskim parkiem narodowym, posiada niezwykle barwną historię. Został on utworzony na podstawie przepisów ustawy o ochronie przyrody z $1949 \mathrm{r}$. W procesie tworzenia parku narodowego w Ojcowie pojawił się szereg problemów z zakresu prawa administracyjnego i cywilnego. Największym z nich była kwestia zmieniających się koncepcji zagospodarowania obszaru Ojcowa - kolejno jako uzdrowiska, rezerwatu przyrody oraz parku narodowego. Drugą poważną trudnością była wielkość jego ziemi pozostająca własnością prywatnych właścicieli - około 1/3 pierwotnej powierzchni Ojcowskiego Parku Narodowego. Praca udziela odpowiedzi na dwa podstawowe pytania: jaka konstrukcja prawna została przewidziana przez ustawodawcę w celu utworzenia parku narodowego w Polsce Ludowej oraz jak przepisy regulujące tę tematykę były stosowane w ówczesnej praktyce.
\end{abstract}

Słowa kluczowe: ochrona przyrody; park narodowy; prawo ochrony przyrody

\section{Wstęp}

Pierwsza połowa $\mathrm{XX}$ w. to czas szybkiego rozwoju polskiego prawa ochrony przyrody. Już po odzyskaniu przez Polskę niepodległości, w 1918 r., został wydany dekret o opiece nad zabytkami sztuki i kultury, na podstawie którego za zabytki nieruchome mogły zostać uznane m.in. jaskinie, grodziska, głazy, ogrody ozdobne, stare aleje cmentarne i przydrożne, sędziwe i okazałe drzewa.

* Mgr, Uniwersytet Śląski w Katowicach, Wydział Prawa i Administracji, doktorantka w Katedrze Historii Prawa; e-mail: barbara.gach@interia.eu 
Zabytek nieruchomy wraz ze swoim najbliższym otoczeniem nie mógł być burzony, niszczony, przerabiany, odnawiany, rekonstruowany, zdobiony lub uzupełniany bez zezwolenia właściwego konserwatora zabytków sztuki i kultury ${ }^{1}$. 16 września 1919 r. Minister Wyznań Religijnych i Oświecenia Publicznego wydał rozporządzenie o ochronie niektórych zabytków przyrody, które objęło ochroną cenne okazy przyrody nieożywionej, cisy i modrzewie polskie oraz wyszczególnione okazy innych gatunków roślin, a także wybrane gatunki zwierząt (np. bociana czarnego, bobra, świstaka, żubra). Na mocy tych przepisów było zabronione ich niszczenie, uszkadzanie lub wywożenie z kraju, jednak przestrzeganie tej regulacji nie zostało zabezpieczone żadną sankcją ${ }^{2}$. Kolejnym aktem prawnym normującym zagadnienia ochrony przyrody było rozporządzenie Rady Ministrów z dnia 10 czerwca 1925 r. o trybie załatwiania spraw ochrony przyrody wchodzących w zakres działania Ministerstwa Wyznań Religijnych i Oświecenia Publicznego, jednak zostały w nim uregulowane jedynie zagadnienia ustrojowe i formalne ${ }^{3}$. Pierwszym polskim ramowym aktem prawnym, poświęconym w całości zagadnieniom ochrony przyrody była ustawa o ochronie przyrody z dnia 10 marca 1934 r. ${ }^{4}$ Przewidywała ona takie formy ochrony przyrody, jak: możliwość uznania poszczególnego tworu przyrody za pomnik przyrody, wprowadzenia ochrony gatunkowej roślin i zwierząt oraz utworzenia parku narodowego, a także regulowała ustrój władz ochrony przyrody na szczeblu centralnym i terenowym. Następną ustawą zajmującą się tą tematyką była ustawa o ochronie przyrody z dnia 7 kwietnia 1949 r. ${ }^{5}$ Obok form ochrony przyrody znanych z poprzedniej regulacji oraz ram organizacyjnych władz i organów ochrony przyrody prawodawca zamieścił w niej również możliwość uznania określonych obszarów za rezerwaty przyrody. Dzięki rezygnacji z niektórych instytucji poprzedniej ustawy i stworzeniu dodatkowych została ona pozbawiona czysto konserwatorskiego charakteru swojej poprzedniczki.

Istnieje wiele opracowań dotyczących parków narodowych w Polsce, w tym także Ojcowskiego Parku Narodowego, jednak większość z nich skupia się wokół

\footnotetext{
Dekret Rady Regencyjnej z dnia 8 listopada 1918 r. o opiece nad zabytkami sztuki i kultury (Dz.U. z 1918 r., nr 16, poz. 36).

2 Rozporządzenie Ministra Wyznań Religijnych i Oświecenia Publicznego z dnia 16 września 1919 r. o ochronie niektórych zabytków przyrody (M.P. z 1919 r., poz. 208).

3 Rozporządzenie to nie zostało opublikowane, natomiast jego przedruk znajdował się w pracy: J.G. Pawlikowski, Prawo ochrony przyrody, Kraków 1927, s. 66, cyt. za: L. Jastrzębski, Ochrona prawna przyrody i środowiska w PRL. Zagadnienia administracyjne, Wydawnictwa Uniwersytetu Warszawskiego, Warszawa 1979, s. 12 i 191.

4 Ustawa z dnia 10 marca 1934 r. o ochronie przyrody (Dz.U. z 1934 r., nr 31, poz. 274).

5 Ustawa z dnia 7 kwietnia 1949 r. o ochronie przyrody (Dz.U. z 1949 r., nr 25, poz. 180).
} 
zagadnień przyrodniczych lub historycznych bądź też pełnią one rolę przewodników. Aspekt prawny, zwłaszcza historycznoprawny, został w tej dziedzinie pominięty, a powstałe opracowania dotyczą raczej całości zagadnień składających się na ochronę przyrody i ochronę środowiska, gdzie parki narodowe zostają najczęściej zestawione $\mathrm{z}$ innymi formami obszarowej ochrony przyrody i poddane analizie prawnoporównawczej. Niemniej moim zdaniem park narodowy jako prawna forma ochrony przyrody jest intrygującym polem badawczym, łączącym w sobie elementy prawa administracyjnego, cywilnego i karnego oraz powiązanym między innymi z takimi zagadnieniami, jak planowanie przestrzenne, prawo własności, prawo budowlane, prawo łowieckie, prawo leśne, ochrona zabytków, masowa turystyka, odpowiedzialność karna i inne. Prawne relacje pomiędzy wskazanymi kwestiami, zwłaszcza w czasach Polski Ludowej, kiedy dopiero kształtowało się funkcjonowanie parków narodowych $\mathrm{w}$ polskim systemie prawnym, stanowią wielopłaszczyznowy materiał do badań.

Ojcowski Park Narodowy ${ }^{6}$, posiadający niezwykle barwną historię, wydaje się być jednym z najodpowiedniejszych ze wszystkich parków narodowych, znajdujących się na ziemiach polskich do przeprowadzenia wskazanych badań. W dziejach tego parku pojawiają się chyba wszystkie wskazane zagadnienia. Ze względu na jego położenie największymi problemami Ojcowa była szeroko rozumiana ochrona przyrody przed zniszczeniami powodowanymi rozwojem przemysłu oraz masowa turystyka. Ponadto problemem wyróżniającym Ojcowski Park Narodowy na tle innych parków narodowych jest wielkość jego terenów pozostająca w rękach prywatnych właścicieli, co w konsekwencji do dnia dzisiejszego rodzi szereg trudności.

\section{Definicja parku narodowego}

Park narodowy zgodnie z definicją encyklopedyczną PWN to „względnie duży obszar objęty ochroną prawną, zachowany w stanie naturalnym lub niewiele zmienionym przez działalność człowieka, powołany w celu ochrony najcenniejszych pod względem przyrodniczym i krajobrazowym terenów wraz z całą ich różnorodnością biologiczną, układami i procesami przyrodniczymi oraz lo-

6 Utworzony w roku 1956 Ojcowski Park Narodowy w chwili utworzenia obejmował obszar o powierzchni około 1440 ha, z czego około $1 / 3$ była własnością pozostającą w rękach prywatnych właścicieli. Park ten jest położony na terenie Wyżyny Krakowsko-Częstochowskiej, w malowniczej Dolinie Prądnika, usytuowanej między Górnośląskim Okręgiem Przemysłowym a miastem Krakowem. Na terenie Ojcowskiego Parku Narodowego występują także liczne zabytki. 
kalnym dziedzictwem kulturowym", natomiast według Słownika języka polskiego $P W N$ to „duży obszar zachowany w stanie naturalnym, podlegający ścisłej ochronie ze względu na szczególne walory przyrodnicze i krajobrazowe" Jak wynika z przytoczonych definicji, park narodowy to obszar znajdujący się pod ochroną prawną ze względu na jego niezmieniony lub niewiele zmieniony działalnością człowieka stan, tworzony w celu ochrony znajdującej się na nim przyrody ożywionej i nieożywionej oraz krajobrazu.

Pierwszy na świecie park narodowy powstał w roku 1872 w Stanach Zjednoczonych - był nim słynny Yellowstone National Park, który zajmował olbrzymią powierzchnię 898000 ha. Następne parki narodowe powstały w Australii - Royal (1879), Kanadzie - Banff (1885) i Nowej Zelandii - Tongariro (1887). W Europie najwcześniej utworzono parki narodowe w Szwecji - Abisko i Sarek (1909), a kolejne powstały w Rosji (1910), Szwajcarii (1914), Hiszpanii (1918) i Włoszech (1922) 9 .

\section{Park narodowy w polskim porządku prawnym}

W polskim porządku prawnym ta forma ochrony przyrody została przewidziana po raz pierwszy w ustawie o ochronie przyrody z 1934 r. ${ }^{10} \mathrm{~W}$ myśl art. 9 ustawy Rada Ministrów uzyskała kompetencję do tworzenia parków narodowych w drodze rozporządzenia, na wniosek złożony przez Ministra Wyznań Religijnych i Oświecenia Publicznego w porozumieniu z Ministrem Rolnictwa i Reform Rolnych, po zasięgnięciu opinii Państwowej Rady Ochrony Przyrody ${ }^{11}$, w sytuacji gdy „ochrana [sic!] przyrody nie może ograniczać się do poszczególnych przedmiotów, lecz powinna jednolicie dotyczyć ich skupień na obszarze co najmniej trzystu hektarów" ${ }^{12}$. W okresie międzywojennym powstały 4 parki

Encyklopedia PWN, https://encyklopedia.pwn.pl/haslo/park-narodowy;3954406.html; stan na 8.08.2018 r.

$8 \quad$ Stownik języka polskiego PWN, https://sjp.pwn.pl/sjp/park-narodowy;2498335.html; stan na 8.08.2018 r.

9 E. Symonides, Ochrona przyrody, Wydawnictwa Uniwersytetu Warszawskiego, Warszawa 2008, s. 401.

10 Ustawa z dnia 10 marca 1934 r. o ochronie przyrody (Dz.U. z 1934 r., nr 31, poz. 274).

11 Państwowa Rada Ochrony Przyrody została utworzona na mocy art. 13 ustawy o ochronie przyrody z roku 1934 jako organ doradczy i opiniodawczy ds. ochrony przyrody działający przy Ministrze Wyznań Religijnych i Oświecenia Publicznego, któremu przewodniczył Delegat Ministra Wyznań Religijnych i Oświecenia Publicznego ds. Ochrony Przyrody.

12 Ustawa z dnia 10 marca 1934 r. o ochronie przyrody (Dz.U. z 1934 r., nr 31, poz. 274). 
narodowe: w roku 1932 Park Narodowy w Pieninach ${ }^{13}$ i Park Narodowy w Białowieży ${ }^{14}$, a rok później Babiogórski i Wielkopolski Park Narodowy ${ }^{15}$; ponieważ miało to miejsce jeszcze przed uchwaleniem pierwszej polskiej ustawy o ochronie przyrody, to z powodu braku podstawy prawnej zostały one utworzone na podstawie $\S 6$ rozporządzenia Prezydenta Rzeczypospolitej z dnia 30 grudnia 1924 r. o organizacji administracji lasów państwowych ${ }^{16}$ jako szczególne jednostki organizacyjne, do których do czasu wydania specjalnych przepisów i instrukcji stosowane miały być przepisy i instrukcje wydane dla nadleśnictw, z uwzględnieniem odrębnego charakteru tych jednostek. Z kolei w czasach Polskiej Rzeczpospolitej Ludowej, w roku 1947, rozporządzeniem wydanym na podstawie ustawy o ochronie przyrody z $1934 \mathrm{r}$. zostało potwierdzone istnienie Białowieskiego Parku Narodowego ${ }^{17}$.

Druga polska ustawa o ochronie przyrody - z 1949 r. - również przewidywała możliwość utworzenia parku narodowego. Została ona zamieszczona w art. 11 pkt 3 ustawy, zaraz po możliwości uznania poszczególnych tworów przyrody lub ich skupień za pomnik przyrody (pkt 1) oraz uznania określonego obszaru za rezerwat przyrody (pkt 2). Zgodnie z art. 14 ustawy utworzenie parku narodowego, tak samo jak w przypadku regulacji międzywojennej, miało nastąpić w drodze rozporządzenia Rady Ministrów wydanego na wniosek Ministra Leśnictwa złożony po zasięgnięciu opinii Państwowej Rady Ochrony Przyrody. Rozporządzenie to miało zawierać: nazwę parku narodowego, określenie obszarów wchodzących $\mathrm{w}$ jego skład, określenie wprowadzanych ograniczeń ${ }^{18} \mathrm{i}$ zasad zagospodarowania, a także ustanowienie władzy podległej Mi-

13 Rozporządzenie Ministra Rolnictwa z dnia 23 maja 1932 r. o utworzeniu z rezerwatu w Pieninach jednostki organizacyjnej szczególnej pod nazwą „Park Narodowy w Pieninach” (M.P. z 1932 r., nr 123, poz. 156).

14 Rozporządzenie Ministra Rolnictwa i Reform Rolnych z dnia 4 sierpnia 1932 r. o utworzeniu z Nadleśnictwa Rezerwat w okręgu Dyrekcji Lasów Państwowych w Białowieży jednostki organizacyjnej szczególnej pod nazwą „Park Narodowy w Białowieży” (M.P. z 1932 r., nr 183, poz. 219).

15 Z. Denisiuk, Z. Dyryga, A. Kalemba i in., Rola parków narodowych w ochronie szaty roślinnej i krajobrazu Polski, Zakład Ochrony Przyrody i Zasobów Naturalnych PAN, Kraków 1991, s. 11.

16 § 6 rozporządzenia zawierał delegację ustawową dla Rady Ministrów do oznaczenia w drodze rozporządzenia liczby, okręgów i siedzib dyrekcji lasów państwowych - Rozporządzenie Prezydenta Rzeczypospolitej z dnia 30 grudnia 1924 r. o organizacji administracji lasów państwowych (Dz.U. z 1924 r., nr 119, poz. 1079).

17 Rozporządzenie Rady Ministrów z dnia 21 listopada 1947 r. o utworzeniu Białowieskiego Parku Narodowego (Dz.U. z 1947 r., nr 74, poz. 469).

18 Zgodnie z art. 18 ustawy o ochronie przyrody z roku 1949 do możliwych ograniczeń należały: 1) czasowy lub nieograniczony w czasie zakaz dokonywania wszelkich lub istotnych zmian 
nistrowi Leśnictwa, a powołanej do sprawowania zarządu parku narodowego wraz z określeniem jej zakresu działania. Tą nieco enigmatycznie określoną władzą powołaną do sprawowania zarządu mógł być nadleśniczy państwowy i kierownik parku narodowego (stanowisko to miało dotyczyć tylko parków narodowych, które wchodziły w skład rejonów lasów państwowych) lub dyrektor parku narodowego, a ich kompetencje zostały sprecyzowane dopiero w zarządzeniu Ministra Leśnictwa ${ }^{19}$. Co ważne, zgodnie z ustawą, utworzenie parku narodowego mogło nastąpić tylko na obszarze objętym planem zagospodarowania przestrzennego. Regulacja z 1949 r. zwiększała minimalną powierzchnię obszaru, na którym mógł zostać utworzony park narodowy - wynosiła ona co najmniej 500 hektarów ${ }^{20}$. Jak nietrudno zauważyć, w porównaniu z wcześniejszą konstrukcją - została ona zachowana w całości, a ustawodawca wprowadził jedynie niewielkie zmiany. Do końca istnienia Polskiej Rzeczpospolitej Ludowej utworzono w Polsce w sumie 15 parków narodowych ${ }^{21}$, a w roku 1990, również na podstawie art. 14 ustawy o ochronie przyrody z 1949 r., 2 kolejne.

Zastanawiające jest, dlaczego w obu ustawach polski prawodawca zdecydował się przyjąć nazwę ,park narodowy” dla tej formy ochrony przyrody. O ile użycie przymiotnika „,narodowy” nie budzi wątpliwości, ponieważ oznacza on tyle co „pewnemu narodowi właściwy, do pewnego narodu należący”22

przedmiotów; 2) zakaz: używania, użytkowania, uszkadzania i zanieczyszczania przedmiotów lub terenów; 3) zakaz: polowania, rybołówstwa, chwytania i zabijania dziko żyjących zwierząt, zbioru z dzikiego stanu niektórych roślin leczniczych lub ich części oraz niszczenia lub uszkadzania drzew i innych roślin, zanieczyszczania wody i zmiany jej biegu, niszczenia gleby, wydobywania skał i minerałów oraz wzniecania ognia; 4) zakaz: zbywania, nabywania, przewożenia lub wywożenia za granicę przedmiotów; 5) zakaz: umieszczania na określonych przedmiotach lub na określonych terenach tablic, napisów, ogłoszeń reklamowych i innych znaków oraz zakłócania ciszy; 6) zakaz: wznoszenia budowli w ogóle lub w określonym rozmiarze, charakterze i sposobie użytkowania, jak również wznoszenia i prowadzenia zakładów przemysłowych lub handlowych oraz urządzeń komunikacyjnych i innych urządzeń technicznych; 7) regulowanie dostępu do określonych przedmiotów lub określonych terenów, wyjąwszy ich właścicieli, użytkowników i posiadaczy oraz ich domowników i najemnych pracowników.

19 Zarządzenie Ministra Leśnictwa z dnia 20 listopada 1950 r. w sprawie zakresu czynności konserwatora przyrody, nadleśniczego państwowego, kierownika parku narodowego i dyrektora parku narodowego w dziedzinie ochrony przyrody (M.P. z 1950 r., Nr A-132, poz. 1646).

20 Ustawa z dnia 7 kwietnia 1949 r. o ochronie przyrody (Dz.U. z 1949 r., nr 25, poz. 180).

21 W tym władze Polskiej Rzeczypospolitej Ludowej wydały rozporządzenia ponownie tworzące parki narodowe powstałe już w okresie międzywojennym (Pieniński Park Narodowy, Białowieski Park Narodowy, Babiogórski Park Narodowy i Wielkopolski Park Narodowy).

22 J. Karłowicz, A. Kryński, W. Niedźwiedzki (red.), Słownik języka polskiego, tom III N-Ó, nakładem prenumeratorów i Kasy im. Mianowskiego, w drukarni „Gazety Handlowej”, Warszawa 1904, s. 147. 
lub „dotyczący narodu, ogółu mieszkańców pewnego terytorium”23, a właśnie takim dobrem bez wątpienia jest park narodowy, to jednak rzeczownik ,park” nie wydaje się być trafnym wyborem, gdyż w języku polskim terminem tym określany był „wielki ogród ozdobny, urządzony na kształt lasku” ${ }^{24}$, a także „wielki ogród ozdobny z alejami i ścieżkami spacerowymi”"25, co przywodzi na myśl jakiś twór działalności człowieka, którym park narodowy z pewnością nie jest. Ponadto, jak pisał L. Jastrzębski, wraz z rozwojem ogrodów (krajobrazowych) tworzonych przez polskich królów, magnatów, a także i bogatszą szlachtę w okresie renesansu i baroku, pojawiła się nazwa „park” obejmująca swym znaczeniem ogród pozostający w harmonijnym układzie $\mathrm{z}$ otaczającym go krajobrazem ${ }^{26}$. Biorąc to pod uwagę, przypuszczać można, że najprawdopodobniej legislator zastosował to rozwiązanie na wzór amerykański - tłumacząc nazwę national park na język polski. Hipotezę tę potwierdza fakt, że dopiero w roku 1969 w New Delhi X Ogólne Zgromadzenie Międzynarodowej Unii Ochrony Przyrody i Jej Zasobów ${ }^{27}$ w rezolucji nr 1 zaleciło, by nazwa „park narodowy" została zachowana przez rządy wszystkich krajów jedynie dla spełniających wymagania ustanowionej wówczas definicjii ${ }^{28}$ obszarów $^{29}$. W dalszej

23 Stownik języka polskiego pod red. W. Doroszewskiego, https://sjp.pwn.p1/doroszewski/narodowy;5455983.html; stan na 8.08.2018 r.

24 A. Kryński, W. Niedźwiedzki (red.), Stownik języka polskiego, tom IV P-Prożyszcze, nakładem prenumeratorów i Kasy im. Mianowskiego, w drukarni „Gazety Handlowej”, Warszawa 1908, s. 60.

25 https://sjp.pwn.pl/doroszewski/park-I;5469891.html; stan na 8.08.2018 r.

26 L. Jastrzębski, Prawne zagadnienia ochrony przyrody, Wydawnictwo Prawnicze, Warszawa 1980, s. 9.

27 Międzynarodowa Unia Ochrony Przyrody to utworzone w 1948 r. stowarzyszenie członkowskie działające na rzecz ochrony przyrody, którego nazwa w roku 1956 została zmieniona w Zgromadzenie Międzynarodowej Unii Ochrony Przyrody i Jej Zasobów - zob. więcej: https://www.iucn.org.pl/pl/o-nas/iucn

28 Park narodowy jest to obszar stosunkowo rozległy:

1) który przedstawia jeden lub kilka ekosystemów mało lub zupełnie niezmienionych przez użytkowanie lub osadnictwo człowieka, gdzie gatunki roślin i zwierząt oraz przyroda nieożywiona mają szczególne znaczenie dla celów naukowych, wychowawczych i wypoczynkowych albo gdzie istnieją krajobrazy naturalne o dużym znaczeniu estetycznym;

2) na którym władze danego kraju zastosowały odpowiednie środki, aby przeszkodzić gospodarczemu użytkowaniu zasobów przyrody, celem utrzymania wartości naturalnych: ekologicznych, geomorfologicznych i krajobrazowych;

3) którego zwiedzanie udostępnia się - pod pewnymi warunkami - dla celów wypoczynkowych, wychowawczych czy kulturalnych.

29 J. Gawłowska, M. Gawłowska, Parki narodowe, obszary chronionego krajobrazu, rezerwaty i pomniki przyrody żywej w Polsce (z uwzględnieniem ich opracowania naukowego), 
części przedstawione zostaną trudności interpretacyjne, które wystąpiły w praktyce, a które wynikały z przyjęcia tego nazewnictwa.

Jak już wspomniano wyżej, ustawa o ochronie przyrody z 1949 r. przewidywała, że park narodowy może zostać utworzony w drodze rozporządzenia, podczas gdy uznanie za rezerwat przyrody było dokonywane w formie zarządzenia Ministra Leśnictwa, a uznanie za pomnik przyrody następowało w formie decyzji administracyjnej władzy ochrony przyrody II instancji. Park narodowy był więc formą ochrony przyrody wyróżniającą się spośród pozostałych form najwyższą rangą tworzącego go aktu prawnego. Ponadto park narodowy był jednostką budżetową podporządkowaną bezpośrednio Ministrowi Leśnictwa, natomiast rezerwat przyrody był niesamodzielną jednostką wchodzącą w skład nadleśnictwa ${ }^{30}$. Tak przyjęta konstrukcja parku narodowego sprawiała, że to właśnie ta forma ochrony przyrody mogła realizować zadania ochronne w sposób najbardziej kompleksowy i przede wszystkim samodzielny. Jednocześnie wiązało się to ze zwiększonymi wymaganiami ustanowionymi wobec obszaru, na którym miał zostać utworzony park narodowy - jego powierzchnia nie mogła być mniejsza niż 500 ha, a także musiała być ona objęta planem zagospodarowania przestrzennego. Spośród dwóch pozostałych ówczesnych form ochrony przyrody park narodowy wyróżniał się także sposobem powstania - mianowicie był on „tworzony”, podczas gdy poszczególne twory przyrody lub ich skupienia mogły zostać „uznane” za pomniki przyrody tak samo jak określone obszary mogły zostać „uznane” za rezerwaty przyrody. Różnica w nazewnictwie zastosowanym przez ustawodawcę wynikała najpewniej stąd, że wraz z powstaniem parku narodowego tym samym tworzona była państwowa jednostka budżetowa.

\section{Utworzenie parku narodowego w praktyce na przykładzie Ojcowskiego Parku Narodowego}

Tworzenie parków narodowych na terenie Polski było poprzedzone wieloletnimi staraniami, które podejmowane były ze zmiennym powodzeniem. To jak trudny, żmudny i wieloetapowy był to proces, ukazuje przebieg prac mających na celu stworzenie jako szóstego w Polsce ${ }^{31}$ Ojcowskiego Parku Narodowego. Tylko na przestrzeni 33 lat pojawiały się trzy różne koncepcje zagospodarowa-

w: W. Michajłow (red.), Ochrona przyrodniczego środowiska człowieka, Państwowe Wydawnictwo Naukowe, Warszawa 1976, s. 683-684.

30 L. Jastrzębski, op. cit., s. 85-86.

31 A. Zachariasz, Ojcowski Park Narodowy, Czasopismo Techniczne 2008/1-A, s. 6. 
nia tego obszaru, a mianowicie: powstanie uzdrowiska, uznanie go za rezerwat i utworzenie parku narodowego.

Ojców to miejscowość ciesząca się średniowiecznym rodowodem, do trzeciego rozbioru Polski był królewszczyzną ${ }^{32}$, potem stał się własnością prywatną. W drugiej połowie XIX w. ojcowskie lasy zostały zdewastowane przez wrocławskich kupców, prowadzono także intensywną eksploatację namulisk w grotach na tym terenie. Turyści również przyczyniali się do niszczenia okolicznej przyrody. Działania gospodarcze prowadzone w tym czasie w lasach Ojcowa oraz nierozważne postępowanie turystów spotkały się ze sprzeciwem społeczeństwa, ponadto osoby prywatne zapoczątkowały starania i zabiegi mające na celu ochronę jego przyrody (tj. wykup dóbr ojcowskich i rozpoczęcie prac renowacyjnych) ${ }^{33}$.

Pierwszą z wizji powstałą w wyniku docenienia walorów Ojcowa i postrzegania go jako „estetyczną i klimatyczną osobliwość przyrody polskiej”34 było stworzenie na jego terenie uzdrowiska. Już pod koniec XIX w. w Ojcowie istniało wiele pensjonatów, hoteli i duży dom zdrojowy, a rozwój uzdrowiska trwał nadal ${ }^{35}$. Dnia 16 marca 1923 r. powstała spółka akcyjna „Uzdrowisko Ojców", co zostało ogłoszone w Monitorze Polskim z dnia 6 kwietnia 1923 r. Ojców został faktycznie uznany przez władze państwowe za uzdrowisko, co zagwarantowało mu w jakimś stopniu ochronę przed eksploatacją ${ }^{36}$. W następstwie tych zdarzeń oraz dzięki zakazowi dalszego zabudowywania Doliny Prądnika wydanemu przez Państwową Komisję Ochrony Przyrody ${ }^{37}$ z uwagi na występujące tam zabytki fauny i flory, na lokalizację projektowanego uzdrowiska wybrano Złotą Górę ${ }^{38}$. Uzdrowisko Ojców zakupiło Ojców (obszar leśny o po-

32 J. Partyka, J. Żółciak, Konflikt człowiek - przyroda na przykładzie Ojcowskiego Parku Narodowego, w: A. Hibszer, J. Partyka (red.), Między ochrona przyrody a gospodarka - blizej ochrony, Polskie Towarzystwo Geograficzne Oddział Katowicki, Ojcowski Park Narodowy, Sosnowiec-Ojców 2005, s. 33.

33 M. Gotkiewicz, W. Szafer (oprac.), Ojcowski Park Narodowy, Wydawnictwa Zakładu Ochrony Przyrody PAN, Kraków 1956, s. 82-85.

34 Ojców, broszura wydana przez Komitet Rozbudowy Osiedla Uzdrowiskowego Ojców, Kraków 1927, s. 6.

35 J. Partyka, Ojcowski Park Narodowy, Zakład Narodowy im. Ossolińskich, Wrocław 1976, s. 10.

36 Ibidem, s. 15.

37 Państwowa Komisja Ochrony Przyrody to powołany w 1920 r. organ doradczy i opiniodawczy władz państwowych w sprawach ochrony przyrody przekształcony później w Państwową Radę Ochrony Przyrody. Zob. https:/encyklopedia.interia.pl/biologia-rolnictwo/ekologia/ news-panstwowa-rada-ochrony-przyrody,nId,1982353

38 Ojców..., s. 7. 
wierzchni 77,78 ha) od Marii Ludwiki Czartoryskiej z jej majątku Podzamcze k. Ojcowa i Kolęcina. Pozyskana ziemia została rozparcelowana na działki leśne o powierzchni $1800 \mathrm{~m}^{2}$ każda i zgodnie z postanowieniami statutu Uzdrowiska $1 / 3$ tych parcel mogła zostać wylesiona pod zabudowania. Powstałe w ten sposób parcele zostały uzbrojone, stworzony został także plan osiedla, wytyczono ulice itd. W ten sposób stworzono 358 parcel, z których spółka sprzedała 259, a po jej likwidacji niesprzedane działki zostały wykupione przez Marię Ludwikę Czartoryską. W okresie Polskiej Rzeczpospolitej Ludowej majątek leśny do niej należący został upaństwowiony, wskutek czego parcele stały się własnością Skarbu Państwa ${ }^{39}$. Według innego źródła księżna Czartoryska przekazała tę część swojego majątku Komitetowi Rozbudowy Osiedla Uzdrowiskowego Ojców za darmo ${ }^{40}$. Zgodnie z założeniami planu osiedla uzdrowiskowego miało powstać 366 parcel o łącznej powierzchni ok. 60 ha, a pozostałe 40 ha miały zostać przeznaczone na parki, drogi i inne elementy użyteczności publicznej (w tym celu Państwowa Komisja Ochrony Przyrody zwolniła wskazany obszar spod zakazu rozbudowy). Oprócz tego Komitet planował szereg inwestycji, do których należały między innymi: ukończenie budowy drogi Kraków - Ojców, zbudowanie sieci kanalizacji, sieci wodociągowej, sieci instalacji elektrycznej oraz sieci dróg ${ }^{41}$. W tym okresie zbudowano drogę przez Ojców łączącą go z Krakowem i Olkuszem. Tylko dzięki groźbie ówczesnego Ministra Wyznań Religijnych i Oświecenia Publicznego - Sławomira Czerwińskiego ${ }^{42}$, który zagroził dymisją $a^{43}$, oraz dzięki działalności Państwowej Rady Ochrony Przyrody ${ }^{44}$ droga ta nie została poprowadzona przez wyjątkowo cenną przyrodniczo i unikatową Dolinę Sąspowską, a została wytyczona zgodnie z postulatami ochrony przyrody.

Następną była idea stworzenia w Ojcowie rezerwatu. Niemal równocześnie z walorami Ojcowa jako miejscowości uzdrowiskowej dostrzeżono także konieczność objęcia tego obszaru ochroną rezerwatową, co znalazło odbicie

39 Pismo Rejonu Lasów Państwowych w Krakowie z dnia 14 grudnia 1950 r., nr T-1-1029/3/50 do Wojewódzkiej Komisji Planowania Gospodarczego Prezydium Wojewódzkiej Rady Narodowej w Krakowie, Archiwum Nauki Polskiej Akademii Nauk i Polskiej Akademii Umiejętności (dalej: AN PAN i PAU Kr), Zakład Ochrony Przyrody (dalej ZOP), ZOP-141, brak paginacji.

40

41

42

43 Protokół z konferencji odbytej w dniu 21 września 1951 r. w ZOP PAU Kr w sprawie rezerwatów na terenie Ojcowa, maszynopis AN PAN i PAU Kr, ZOP, ZOP-141, brak paginacji.

Ojców..., s. 7.

Ibidem.

Sławomir Czerwiński był Ministrem Wyznań Religijnych i Oświecenia Publicznego w latach J. Partyka, Ojcowski Park Narodowy, s. 18. 
w pierwszym opracowanym w roku 1924, między innymi przez Władysława Szafera $^{45}$ oraz Stanisława Richtera ${ }^{46}$, projekcie rezerwatu ${ }^{47}$. Utworzenie w Ojcowie rezerwatu przyrody zaczęła więc projektować już w roku 1924 Państwowa Rada Ochrony Przyrody, jednak zamierzonego celu nie udało się osiągnąć. Początkowo z powodu braku podstaw prawnych - ustawa o ochronie przyrody weszła w życie dopiero w 1934 r., a akty wykonawcze w latach 1936-1937; następnie działania utrudnił kryzys wewnętrzny w Państwowej Radzie Ochrony Przyrody, aż ostatecznie wybuch II wojny światowej zahamował wszelkie prace. Objęcie Ojcowa ochroną rezerwatową pozostało w fazie projektu, a kondycja przyrodnicza jego obszaru ciągle się pogarszała.

Po zakończeniu wojny na nowo rozpoczęto działania mające na celu objęcie Ojcowa prawną ochroną. W dniu 29 sierpnia 1946 r. Wojewódzka Rada Narodowa w Krakowie podjęła uchwałę, która przewidywała powstanie rezerwatu Jury Krakowsko-Wieluńskiej. Nie została ona w pełni zrealizowana pomimo utworzenia przez Ministerstwo Leśnictwa rezerwatów na obszarze lasów państwowych Jury Krakowsko-Wieluńskiej z powodu nieuregulowania ich form prawnych $^{48}$. W roku 1947 ponownie podjęto próby utworzenia w Ojcowie rezerwatu przyrody, jednak również te plany nie zostały zrealizowane z powodu braku map katastralnych i wykazów hipotecznych tego terenu ${ }^{49}$. Rok 1947 to także czas porażek w zakresie działań ochronnych w Ojcowie - Dyrekcja Lasów Państwowych, nie zasięgając opinii delegata Ministra Oświaty do spraw Ochrony Przyrody, zatwierdziła plan gospodarczy Ojcowa, zgodnie z którym dozwolona została pełna eksploatacja ojcowskich lasów. W wyniku interwencji powstrzymano dalsze pozyskiwanie drewna, jednak zanim to nastąpiło, zostało wyciętych wiele drzew, m.in. reliktowe sosny o ogromnym znaczeniu naukowym $^{50}$. Natomiast już w 1949 r. po raz pierwszy pojawiła się myśl, z którą wy-

45 Władysław Szafer to jeden z pionierów ruchu ochrony przyrody w Polsce, zasłużony działacz na rzecz ochrony przyrody, botanik, profesor Uniwersytetu Jagiellońskiego, dyrektor krakowskiego Ogrodu Botanicznego, wieloletni dyrektor Instytutu Botaniki UJ, założyciel i dyrektor Zakładu Ochrony Przyrody PAN w Krakowie oraz Zakładu (Instytutu) Botaniki PAN, przewodniczący Państwowej Rady Ochrony Przyrody, Delegat Ministra Oświaty do Spraw Ochrony Przyrody, honorowy członek Międzynarodowej Unii Ochrony Przyrody i jej Zasobów.

46 A. Zachariasz, op. cit., s. 6.

47 J. Partyka, Ojcowski Park Narodowy, s. 10.

48 Protokół z konferencji odbytej w dniu 21 września 1951 r. w lokalu ZOP PAU Kr w sprawie rezerwatów na terenie Ojcowa...

49 J. Partyka, Ojcowski Park Narodowy, s. 20.

50 Protokół z konferencji odbytej w dniu 21 września 1951 roku w lokalu ZOP PAU Kr w sprawie rezerwatów na terenie Ojcowa... 
stąpił przedstawiciel Ministerstwa Leśnictwa, aby zamiast rezerwatu przyrody utworzyć park narodowy. Projekt granic Ojcowskiego Parku Narodowego opracował Komitet Ochrony Przyrody Polskiej Akademii Umiejętności w Krakowie, Ministerstwo Leśnictwa opracowało także swój projekt ${ }^{51}$.

W dniu 28 maja 1948 r. został złożony przez Delegata Ministra Oświaty do spraw Ochrony Przyrody (w porozumieniu z Dyrekcją Lasów Państwowych Okręgu Krakowskiego) do Urzędu Wojewódzkiego w Krakowie wniosek o utworzenie terenów chronionych (rezerwatu) obejmujących obszar od Prądnika Korzkiewskiego, wraz z Doliną Sąspowską, aż po Pieskową Skałę ${ }^{52}$. Włączenie terenu Ojcowa do obszaru przyrody chronionej zaczęło odnosić pierwsze skutki - gospodarcze wykorzystanie tych terenów zostało częściowo zatrzymane - np. wstrzymana została dzierżawa gruntów: dnia 27 lutego 1951 r. Rejon Lasów Państwowych w Krakowie przesłał Gminnej Spółdzielni Samopomoc Chłopska Cianowice w Ojcowie odpowiedź odmowną w sprawie dzierżawy, ponieważ, jak uzasadniał swoją decyzję, teren ten stanowił część składową rezerwatu przyrody i przyszłego parku narodowego ${ }^{53}$. Jednak sukces nie był całkowity - jeszcze w grudniu 1950 r. Rejon Lasów Państwowych zwrócił się z prośbą do Wojewódzkiej Komisji Planowania Gospodarczego Prezydium Wojewódzkiej Rady Narodowej w Krakowie o wyjaśnienie, czy w planach zagospodarowania przestrzennego powierzchni leśnej byłej spółki akcyjnej „Uzdrowisko Ojców” przewidziano urządzenie uzdrowiska, czy urządzenie gospodarstwa leśnego, a także, czy w przypadku braku planów zagospodarowania przestrzennego jest to powierzchnia leśna, czy też powierzchnia przeznaczona na cele inne niż leśne. W piśmie Rejonu Lasów Państwowych zastanawiano się również, czy zaplanowanie uzdrowiska nie byłoby sprzeczne z projektowanym utworzeniem Parku ${ }^{54}$.

W ten właśnie sposób koncepcja ustanowienia rezerwatu przyrody na terenie Ojcowa i okolic płynnie przeplatała się z wizją utworzenia w tym miejscu

51 Ibidem.

52 Pismo Delegata Ministra Oświaty do spraw Ochrony Przyrody - prof. dr Władysława Szafera w sprawie utworzenia rezerwatu w Ojcowie z dnia 21 czerwca 1948 r. do Nadleśnictwa Państwowego w Ojcowie, AN PAN i PAU Kr, Państwowa Rada Ochrony Przyrody (dalej: PROP), PROP-389, brak paginacji.

53 Pismo Rejonu Lasów Państwowych w Krakowie z dnia 27 lutego 1951 r., nr NT-2025/4/51 do Gminnej Spółdzielni Samopomocy Chłopskiej Cianowice w Ojcowie, AN PAN i PAU Kr, ZOP, ZOP-141, brak paginacji.

54 Pismo Rejonu Lasów Państwowych w Krakowie z dnia 14 grudnia 1950 roku, nr T-11029/3/50 do Wojewódzkiej Komisji Planowania Gospodarczego Prezydium Wojewódzkiej Rady Narodowej w Krakowie, AN PAN i PAU Kr, ZOP, ZOP-141, brak paginacji. 
parku narodowego. Do pomysłu utworzenia parku narodowego na terenie Ojcowa powrócono ostatecznie na konferencji zorganizowanej w dniu 21 września 1951 r. w Zakładzie Ochrony Przyrody PAU przez Władysława Szafera ${ }^{55}$. Obszar rezerwatów na terenie Lasów Państwowych Ojcowa wynosił łącznie 955,25 ha, a więc zgodnie z wymaganiami ustawowymi teren ten predestynowany był do utworzenia parku narodowego. Dostrzegano także przewagę reżimu ochronnego parku narodowego nad reżimem ochronnym rezerwatu: rezerwat przyrody nie mógł bowiem stanowić samodzielnej jednostki administracyjno-gospodarczej, ale musiał być związany z nadleśnictwem, które było jednostką nastawioną na eksploatację i dochodowość, a nie na ochronę przyrody. Ponadto z pojęciem „rezerwatu” wiązało się bierne i konserwatorskie podejście do zagadnienia - zabezpieczenie określonego terenu przed zniszczeniem, zaś rejon Ojcowa oprócz zagadnień ochronnych wymagał ujęcia w ramy prawne i organizacyjne wielu zagadnień, takich jak między innymi: masowa turystyka (pojawiały się nawet głosy, aby do czasu utworzenia w Ojcowie parku narodowego zamknąć masowy ruch turystyczny, jak i przeciwne temu pomysłowi, jednak dostrzegające powagę problemu i proponujące, by nad turystyką w Ojcowie czuwał park narodowy), administracja i właściwe użytkowanie gruntów, występowanie zabytków historycznych, zagadnień naukowych, rozległy problemem własności prywatnej (który mógł zostać rozwiązany jedynie poprzez wykup i zamianę gruntów prywatnych) - niezbędne więc wydawało się utworzenie samodzielnej jednostki administracyjnej, posiadającej ustawowe uprawnienia ${ }^{56}$. W konsekwencji przyjęto jednomyślnie następujące tezy, będące wyrazem opinii wypowiadanych przez uczestników:

1) należało utworzyć park narodowy;

2) z powodu ogromnych zniszczeń należało dążyć do tego, aby prace nad utworzeniem Ojcowskiego Parku Narodowego rozpocząć natychmiast, tak aby Dyrekcja Parku zaczęła działać przed czerwcem 1952 r.;

3) Rejon Lasów Państwowych i Nadleśnictwo nie mogły zajmować się kwestiami ochrony przyrody i kwestiami podobnymi w Ojcowie.

Ponadto Władysław Szafer uważał, że w skład parku oprócz gruntów państwowych powinny wejść również tereny prywatne, a w promieniu $1 \mathrm{~km}$ od granic rezerwatu należało wprowadzić ochronę krajobrazu. Zgodnie z opinią uczestników konferencji w obręb Ojcowskiego Parku Narodowego powinny były

\footnotetext{
J. Partyka, Ojcowski Park Narodowy, s. 20.

56 Protokół z konferencji odbytej w dniu 21 września 1951 r. w ZOP PAU Kr w sprawie rezerwatów na terenie Ojcowa...
} 
wejść: tereny lasów państwowych Nadleśnictwa Ojców (Uroczysko Ojców - Oddziały 1-14 o powierzchni 767,20 ha, Uroczysko Pieskowa Skała - Oddziały 1-7 o powierzchni 157,13 ha i Uroczysko Gawłówek - Oddział 121 o powierzchni 30,92 ha), tereny PGR o powierzchni około 8,80 ha, park w Pieskowej Skale o powierzchni 4,15 ha, a także tereny prywatne stanowiące całość fizjograficzną z terenami państwowymi (gromada Sułoszowa, tereny położone na północny zachód od Pieskowej Skały, tereny między Pieskową Skałą a Ojcowem tworzące strome zbocza Doliny Prądnika aż po krawędź wyżyny i należące do gromady Wola Kalinowska i gromady Skała, tereny gromady Prądnik Korzkiewski, tworzące strome zbocza Doliny Prądnika między Lasami Państwowymi Ojców a rezerwatem Hamernia), których powierzchnia wynosiła około 375,50 ha. Łączny obszar projektowanego parku narodowego miał więc wynosić 1340,75 ha $\mathrm{h}^{57}$.

Zakład Ochrony Przyrody podjął się opracowania ogólnej dokumentacji przyrodniczej i przestrzennej projektowanego Ojcowskiego Parku Narodowego dopiero w roku $1952^{58}$, a zadanie to zostało zlecone Stefanowi Gutowi, Stanisławowi Smólskiemu i Marii Drza159. Szczęśliwie, na mocy zarządzenia Prezydium Wojewódzkiej Rady Narodowej w Krakowie z dnia 27 listopada 1951 r. L.K1.K.III-1-40/51 (Dz.U. W.R.N nr 1, poz. 1/1952 r.) Gromada Ojców i gromady sąsiednie zostały uznane za miejscowości, których krajobraz zasługuje na ochro$n^{60}{ }^{60}$. Jednak pomimo nasilonych działań mających na celu utworzenie w Ojcowie parku narodowego myśl o zbudowaniu osiedla uzdrowiskowego na Złotej Górze była nadal żywa. W związku z tym niezbędne było opracowanie opinii, czy zamierzenie to nie koliduje z projektem utworzenia parku narodowego w Ojcowie oraz sporządzenie planu granic projektowanego parku ${ }^{61}$. Wojewódzki Komitet Ochrony Przyrody w Krakowie w Opinii w sprawie lokalizacji ośrodka wypoczynku

57 Ibidem.

58 Pismo Przewodniczącego Komisji Parków Narodowych i Rezerwatów Państwowej Rady Ochrony Przyrody - prof. dr M. Klimaszewskiego z dnia 28 kwietnia 1952 r. do zastępcy przewodniczącego Państwowej Rady Ochrony Przyrody - mgr. inż. M. Kreutzingera, AN PAN i PAU Kr, ZOP, PROP, Komisja Parków Narodowych i Rezerwatów (dalej KPNiR), ZOP-195, brak paginacji.

Pismo Przewodniczącego Komisji Parków Narodowych i Rezerwatów Państwowej Rady Ochrony Przyrody - prof. dr. M. Klimaszewskiego z dnia 6 sierpnia 1952 r. do inż. Huberta Bodnara - Radcy Ministra Leśnictwa do Spraw Ochrony Przyrody, AN PAN i PAU Kr, ZOP, PROP, KPNiR, ZOP-195, brak paginacji.

60 Pismo Prezydium Wojewódzkiej Rady Narodowej Wydział Budownictwa w Krakowie z dnia 12 stycznia 1952 r. L.Bud.III-5/1/52 do Prezydium Powiatowej Rady Narodowej Wydział Budownictwa w Olkuszu, AN PAN i PAU Kr, ZOP, ZOP-141, brak paginacji.

${ }^{61}$ Pismo Wiceprzewodniczącego Wojewódzkiej Komisji Planowania Gospodarczego Prezydium Wojewódzkiej Rady Narodowej w Krakowie z dnia 6 marca 1952 r. PL III/15/2-52 do Komitetu Ochrony Przyrody PAU w Krakowie, AN PAN i PAU Kr, ZOP, ZOP-141, brak paginacji. 
świątecznego w Ojcowie wypowiadał się przeciw pomysłowi budowy uzdrowiska, krytycznie go oceniając, głównie ze względu na fakt, że projektowany przez Komitet dla spraw Turystyki ośrodek wypoczynku świątecznego w Ojcowie miał obsłużyć dziennie ok. 3000 ludzi i zająć powierzchnię 10-15 ha. Ponadto Wojewódzki Komitet Ochrony Przyrody wskazywał na brak rozróżnienia pojęć „,parku rozrywki” (,parku kultury”) i „parku narodowego”. Pierwszy z nich służyć miał bowiem dostarczaniu ,szeregu rozrywek kulturalnych jak muzyki, występów estradowych, tańca, filmu, czytelni i kawiarni, itp." ${ }^{\prime 2}$, a drugi miał na celu umożliwić człowiekowi „kontakt z możliwie pierwotną przyrodą oraz oddziaływanie na organizm ludzki przez kojący wpływ lasów, wód, pięknego krajobrazu, roślin i zwierząt, ciszy i spokoju"63 a także posiadał on ogromne znaczenie naukowe, które niejednokrotnie mogło nawet przewyższać jego znaczenie turystyczne. Pomimo negatywnego stanowiska w sprawie budowy osiedla uzdrowiskowego na terenie Ojcowa z powodu masowej turystyki, która do tej pory w Ojcowie nie została odpowiednio zorganizowana, Wojewódzki Komitet Ochrony Przyrody w Krakowie dostrzegał konieczność utworzenia ośrodka turystycznego (istotne było stworzenie zwłaszcza: schroniska turystycznego, jadłodajni turystycznej, zorganizowanego i przeszkolonego przewodnictwa turystycznego oraz rozwiązanie zagadnień komunikacyjnych) ${ }^{64}$.

Starania objęcia ochroną Ojcowa i jego okolic, po kilkuletnich intensywnych działaniach w tym kierunku, w końcu zostały zwieńczone sukcesem. Opracowany w latach 1953-1954 przez Stanisława Smólskiego - Wojewódzkiego Konserwatora Przyrody w Krakowie i Tadeusza Szczęsnego - sekretarza Państwowej Rady Ochrony Przyrody projekt rozporządzenia Rady Ministrów w sprawie Ojcowskiego Parku Narodowego został zatwierdzony w 1955 r. ${ }^{65}$, a rozporządzeniem z dnia 14 stycznia 1956 r. został w końcu utworzony Ojcowski Park Narodowy ${ }^{66}$. W krótkim czasie po utworzeniu Ojcowskiego Parku Narodowego powołano Radę Parku, która odbyła swoje pierwsze posiedzenie dnia 16 lipca 1956 r. ${ }^{67}$

62 Opinia Wojewódzkiego Komitetu Ochrony Przyrody w Krakowie Opinia w sprawie lokalizacji ośrodka wypoczynku świątecznego w Ojcowie z kwietnia 1955 r., maszynopis AN PAN i PAU Kr, ZOP, ZOP-141, brak paginacji.

63 Ibidem.

64 Ibidem.

65 J. Partyka, Ojcowski Park Narodowy, s. 21.

66 Rozporządzenie Rady Ministrów z dnia 14 stycznia 1956 r. w sprawie utworzenia Ojcowskiego Parku Narodowego (Dz.U. z 1956 r., nr 4, poz. 22).

67 J. Partyka, Pięćdziesiąt lat Ojcowskiego Parku Narodowego (1956-2006), Ojcowski Park Narodowy, Ojców 2008, s. 5. 
Ojcowski Park Narodowy położony był w powiecie olkuskim, w województwie krakowskim, a swoją powierzchnią, na której zostały utworzone rezerwaty ścisłe i rezerwaty częściowe, obejmował około 1440 ha. Zarząd nad Ojcowskim Parkiem Narodowym sprawował dyrektor Ojcowskiego Parku Narodowego mianowany przez Ministra Leśnictwa, a jego organem doradczym w zakresie zarządzania Parkiem była Rada Ojcowskiego Parku Narodowego powoływana przez Ministra Leśnictwa ${ }^{68}$. Na mocy rozporządzenia w sprawie utworzenia Ojcowskiego Parku Narodowego został także wprowadzony szereg ograniczeń i zakazów obowiązujących na terenie Parku, takich jak przykładowo: zakaz zanieczyszczania terenu, zakaz polowania, chwytania i zabijania dziko żyjących zwierząt, zakaz zanieczyszczania wody, dokonywania zmiany jej biegu z wyjątkiem ujęcia wody dla celów zaopatrzenia w nią ludności, zakaz wznoszenia bez uzgodnienia z Radą Parku zastawek i zapór, zakaz niszczenia gleby, uszkadzania i wydobywania skał i minerałów, zakaz wznoszenia bez uzgodnienia z Radą Parku wszelkich budowli, wchodzących zarówno w zakres budownictwa indywidualnego, jak i budownictwa do celów społecznych, zakaz wznoszenia i prowadzenia zakładów przemysłowych, ograniczenia w ruchu turystycznym oraz wiele innych.

\section{Zakończenie}

Cały opisany tu proces objęcia prawną ochroną ojcowskiej przyrody obrazuje doskonale, że pozornie proste utworzenie parku narodowego przewidziane przez ustawodawcę w ustawie o ochronie przyrody z 1949 r. w praktyce wcale takie łatwe nie było. Wydanie przez Radę Ministrów rozporządzenia o utworzeniu parku narodowego wymagało opracowania projektu rozporządzenia o jego utworzeniu, do którego niezbędne było przede wszystkim: określenie granic projektowanego parku i jego podziału na rezerwaty ścisłe i częściowe, określenie zakazów i ograniczeń obowiązujących na jego obszarze, wskazanie władz parku i ich kompetencji. Ustawa nie określała jednak, kto ani w jaki sposób miał opracować tak szczegółowy projekt. Ponadto, zgodnie z ustawową regulacją, w rozporządzeniu w sprawie utworzenia parku narodowego miała zostać ustanowiona władza do sprawowania zarządu nad tworzonym parkiem - jednak nie zostały określone żadne kryteria dokonywania wyboru tej władzy. W obu tych przypadkach Państwowa Rada Ochrony Przyrody była jedynie organem opiniującym zarówno projekt rozporządzenia, jak i kwalifikacje fachowe kandydatów

68 Rozporządzenie Rady Ministrów z dnia 14 stycznia 1956 r. w sprawie utworzenia Ojcowskiego Parku Narodowego (Dz.U. z 1956 r., nr 4, poz. 22). 
na stanowisko dyrektora lub kierownika parku narodowego. Nie można zapominać także o tym, że ograniczenia i zakazy wprowadzane rozporządzeniem w sprawie utworzenia parku narodowego w pewnym stopniu tworzyły na terenie parku odrębny porządek prawny, różny od obowiązującego na terenie całego kraju w zakresie między innymi: prawa budowlanego, prawa wodnego, prawa leśnego, prawa łowieckiego, gospodarki przestrzennej, prawa górniczego, prawa geologicznego i innych.

Co najważniejsze, samo utworzenie parku narodowego nie rozwiązywało problemu ochrony przyrody na jego terenie. Realizowanie swoich funkcji przez park, przede wszystkim tych ochronnych, ale nie tylko, w praktyce to zagadnienie, które z racji swej obszerności zasługuje bez wątpienia na szersze opracowanie.

\section{Bibliografia}

\section{Akty prawne}

Dekret Rady Regencyjnej z dnia 8 listopada 1918 roku o opiece nad zabytkami sztuki i kultury (Dz.U. z 1918 r., nr 16, poz. 36).

Rozporządzenie Ministra Rolnictwa i Reform Rolnych z dnia 4 sierpnia 1932 r. o utworzeniu z Nadleśnictwa Rezerwat w okręgu Dyrekcji Lasów Państwowych w Białowieży jednostki organizacyjnej szczególnej pod nazwą „Park Narodowy w Białowieży” (M.P. z 1932 r., nr 183, poz. 219).

Rozporządzenie Ministra Rolnictwa z dnia 23 maja 1932 r. o utworzeniu z rezerwatu w Pieninach jednostki organizacyjnej szczególnej pod nazwą „Park Narodowy w Pieninach” (M.P. z 1932 r., nr 123, poz. 156).

Rozporządzenie Ministra Wyznań Religijnych i Oświecenia Publicznego z dnia 16 września 1919 r. o ochronie niektórych zabytków przyrody (M.P. z 1919 r., poz. 208).

Rozporządzenie Prezydenta Rzeczypospolitej z dnia 30 grudnia 1924 r. o organizacji administracji lasów państwowych (Dz.U. z 1924 r., nr 119, poz. 1079).

Rozporządzenie Rady Ministrów z dnia 14 stycznia 1956 r. w sprawie utworzenia Ojcowskiego Parku Narodowego (Dz.U. z 1956 r., nr 4, poz. 22).

Rozporządzenie Rady Ministrów z dnia 21 listopada 1947 r. o utworzeniu Białowieskiego Parku Narodowego (Dz.U. z 1947 r., nr 74, poz. 469).

Ustawa z dnia 10 marca 1934 r. o ochronie przyrody (Dz.U. z 1934 r., nr 31, poz. 274).

Ustawa z dnia 7 kwietnia 1949 r. o ochronie przyrody (Dz.U. z 1949 r., nr 25, poz. 180).

Zarządzenie Ministra Leśnictwa z dnia 20 listopada 1950 r. w sprawie zakresu czynności konserwatora przyrody, nadleśniczego państwowego, kierownika parku narodowego i dyrektora parku narodowego w dziedzinie ochrony przyrody (M.P. z 1950 r., Nr A-132, poz. 1646).

\section{Archiwalia}

Państwowa Rada Ochrony Przyrody, sygnatura: PROP-389, w zbiorach Archiwum Nauki Polskiej Akademii Nauk i Polskiej Akademii Umiejętności. 
Zakład Ochrony Przyrody i Jej Zasobów Polskiej Akademii Nauk w Krakowie. Państwowa Rada Ochrony Przyrody. Komisja Parków Narodowych i Rezerwatów, sygnatura: ZOP-195, w zbiorach Archiwum Nauki Polskiej Akademii Nauk i Polskiej Akademii Umiejętności.

Zakład Ochrony Przyrody, sygnatura: ZOP-141, w zbiorach Archiwum Nauki Polskiej Akademii Nauk i Polskiej Akademii Umiejętności.

\section{Opracowania}

Denisiuk Zygmunt, Dyryga Zofia, Kalemba Andrzej i in., Rola parków narodowych w ochronie szaty roślinnej i krajobrazu Polski, Zakład Ochrony Przyrody i Zasobów Naturalnych PAN, Kraków 1991.

Gawłowska Jadwiga, Gawłowska Maria, Parki narodowe, obszary chronionego krajobrazu, rezerwaty i pomniki przyrody żywej $w$ Polsce ( $z$ uwzględnieniem ich opracowania naukowego), w: Włodzimierz Michajłow (red.), Ochrona przyrodniczego środowiska człowieka, Państwowe Wydawnictwo Naukowe, Warszawa 1976.

Gotkiewicz Marian, Szafer Wladysław (oprac.), Ojcowski Park Narodowy, Wydawnictwa Zakładu Ochrony Przyrody PAN, Kraków 1956.

Jastrzębski Ludwik, Ochrona prawna przyrody i środowiska w PRL. Zagadnienia administracyjne, Wydawnictwa Uniwersytetu Warszawskiego, Warszawa 1979.

Jastrzębski Ludwik, Prawne zagadnienia ochrony przyrody, Wydawnictwo Prawnicze, Warszawa 1980 .

Karłowicz Jan, Kryński Adam, Niedźwiedzki Władysław (red.), Słownik języka polskiego, tom III $N-O$, nakładem prenumeratorów i Kasy im. Mianowskiego, w drukarni „Gazety Handlowej”, Warszawa 1904.

Kryński Adam, Niedźwiedzki Władysław (red.), Stownik języka polskiego, tom IV P-Prożysz$c z e$, nakładem prenumeratorów i Kasy im. Mianowskiego, w drukarni „Gazety Handlowej”, Warszawa 1908.

Ojców, broszura wydana przez Komitet Rozbudowy Osiedla Uzdrowiskowego Ojców, Kraków 1927.

Partyka Józef, Ojcowski Park Narodowy, Zakład Narodowy im. Ossolińskich, Wrocław 1976.

Partyka Józef, Pięćdziesiąt lat Ojcowskiego Parku Narodowego (1956-2006), Ojcowski Park Narodowy, Ojców 2008.

Partyka Józef, Żółciak Jarosław, Konflikt człowiek - przyroda na przykładzie Ojcowskiego Parku Narodowego, w: Adam Hibszer, Józef Partyka (red.), Między ochrona przyrody a gospodarka - blizej ochrony, Polskie Towarzystwo Geograficzne Oddział Katowicki, Ojcowski Park Narodowy, Sosnowiec-Ojców 2005.

Symonides Ewa, Ochrona przyrody, Wydawnictwa Uniwersytetu Warszawskiego, Warszawa 2008.

Zachariasz Agata, Ojcowski Park Narodowy, Czasopismo Techniczne 2008/1-A.

\section{Strony internetowe}

Encyklopedia PWN, https://encyklopedia.pwn.pl; stan na 8.08.2018 r.

Interia encyklopedia, https://encyklopedia.interia.pl; stan na 12.09.2018 r.

Polski Komitet Krajowy Międzynarodowej Unii Ochrony Przyrody, https://www.iucn.org.pl/pl/onas/iucn; stan na 12.09.2018 r.

Stownik języka polskiego PWN, https://sjp.pwn.pl/sjp; stan na 8.08.2018 r.

Słownik języka polskiego PWN pod red. W. Doroszewskiego, https://sjp.pwn.pl/doroszewski; stan na 8.08.2018 r. 
Barbara GACH

\title{
FORMATION OF NATIONAL PARKS IN POLISH PEOPLE'S REPUBLIC ON THE EXAMPLE OF OJCÓW NATIONAL PARK
}

\author{
( Summary)
}

The subject of this article is the process creating process of a national park during the times of Polish People's Republic. The aims of this research is to familiarize with legal issues related to the foundation of the national park and difficulties resulting from this in practice. The analysis of this issue is based on the example of Ojców National Park which is located on the Polish Jurassic Highland at a distance about $16 \mathrm{~km}$ north of Cracow. The Ojców National Park was founded in 1956 and it is the smallest Polish national park, which has an extremely colorful history. It was created under the Law on the Nature Protection Act of 1949. There was a number of problems from the scope of Civil and Administrative Law during the foundation of the National Park in Ojców. The largest of them was a question of changing approaches in the Ojców's area development - in sequence in the Spa town, nature reservation and National Park. The next big problem was the size of the land remains the property of private owners that is about $1 / 3$ of the initial zone of the Ojców National Park. The research explains to the two basic questions: what is the legal arrangement provided for by legislator with the aim to make the foundation of the Natural National Park in Polish People's Republic and legislation regulating which was provided before.

Keywords: nature protection; national park; nature protection law 